\title{
Role of topical insulin therapy as an adjunct in the management
}

\section{of pressure ulcer}

\author{
Shijina Koliyath ${ }^{1}$, Ravi Kumar Chittoria ${ }^{2 *}$, Saurabh Gupta ${ }^{1}$, Chirra Likhitha Reddy ${ }^{1}$, Padmalakshmi Bharathi Mohan ${ }^{1}$, Imran Pathan ${ }^{1}$, Neljo \\ Thomas $^{1}$, Nishad K ${ }^{1}$, Daisy Loyola ${ }^{1}$ \\ ${ }^{1}$ Department of Plastic Surgery, JIPMER, Pondicherry, India. \\ ${ }^{2}$ Head of IT Wing and Telemedicine, Department of Plastic Surgery \& Telemedicine, JIPMER, Pondicherry, India. \\ *Corresponding Author: Dr Ravi Kumar Chittoria, 2Head of IT Wing and Telemedicine, Department of Plastic Surgery \& Telemedicine, \\ JIPMER, Pondicherry, India.
}

Received date: July 16, 2020; Accepted date: August 03, 2020; Published date: August 10, 2020

Citation: Shijina Koliyath, Ravi Kumar Chittoria, Saurabh Gupta, Chirra Likhitha Reddy, Padmalakshmi Bharathi Mohan, Imran Pathan, Neljo Thomas, Nishad K, Daisy Loyola., (2020) Role of topical insulin therapy as an adjunct in the management of pressure ulcer. Clinical Research and Clinical Trials. 2(3); DOI:10.31579/2693-4779/015

Copyright: (c) 2020 Shucheng Gang, This is an open-access article distributed under the terms of The Creative Commons Attribution License, which permits unrestricted use, distribution, and reproduction in any medium, provided the original author and source are credited.

\section{Abstract \\ Pressure ulcer or pressure sore is one of the complications seen in bedridden patients. Management of these ulcers is often challenging. But there is no well-established method that accelerates the wound healing rate. Various adjunctive methods are used for wound bed preparation before definitive reconstruction plan is made. Here we describe our experience in the role of insulin therapy as an adjunct in the management of pressure sores.}

Keywords: Insulin Therapy, Pressure ulcer

\section{Introduction}

Prevention has been a primary goal of pressure ulcer research. Despite such efforts, pressure ulcers remain common in hospitals and in the community. Moreover, pressure ulcers often become chronic wounds that are difficult to treat and that tend to recur after healing.

\section{Materials and Methods}

This study was conducted in plastic surgery department in a tertiary care center in the month of March-April 2020. Informed written consent was taken from the patient. Departmental ethics committee clearance was obtained. The patient was a 30 year male with post-spinal cord injury pressure ulcers on the bilateral ischial region for 3 months.(Figure 1.) The patient was thoroughly investigated. Wound tissue culture was sent and appropriate antibiotic therapy was given. Regular cleaning and dressing was done, but the wound was not showing any good sign of healing. To hasten the wound bed preparation decision was made to give a trial of insulin therapy.

$0.1 \mathrm{ml}$ of regular insulin was injected or sprayed onto $1 \mathrm{~cm} 2$ of the wound when the regular dressing was performed.(Figure 2.) This was repeated once every 3-5 days when the dressing was changed .The wound was reassessed after 2 weeks for evidence of wound healing.

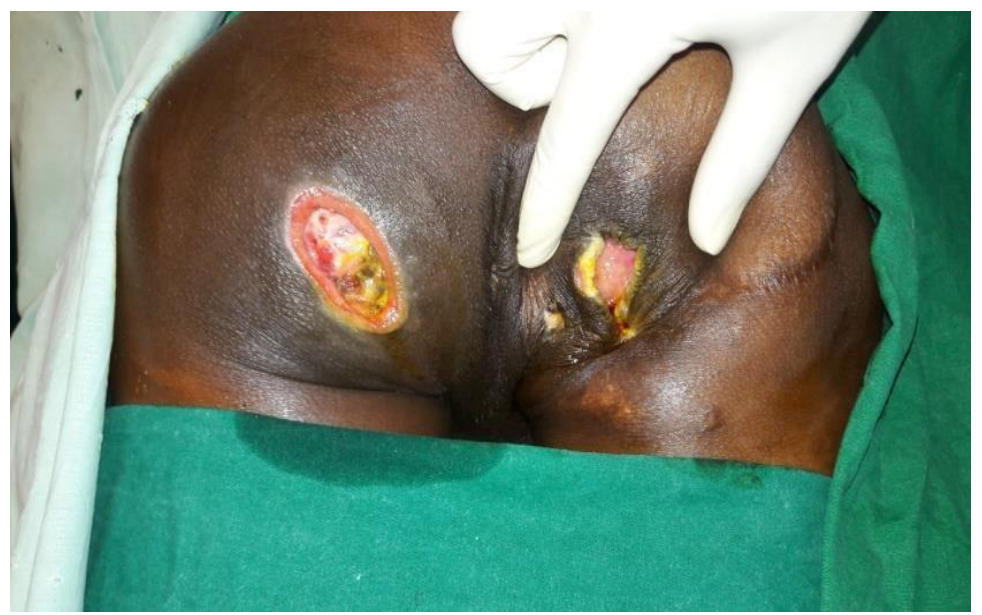

Figure 1. Bilateral ischial pressure sores. 


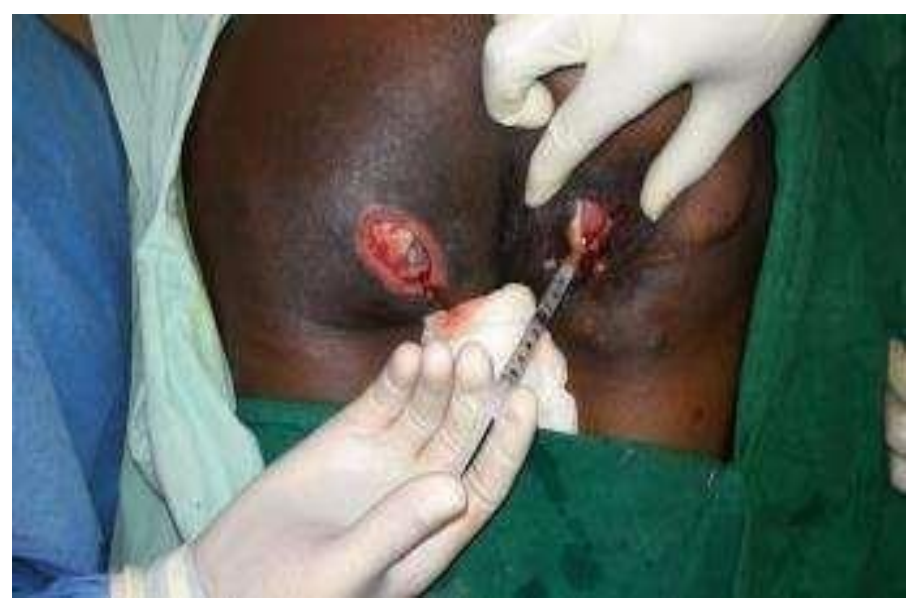

Figure2. Insulin therapy being applied

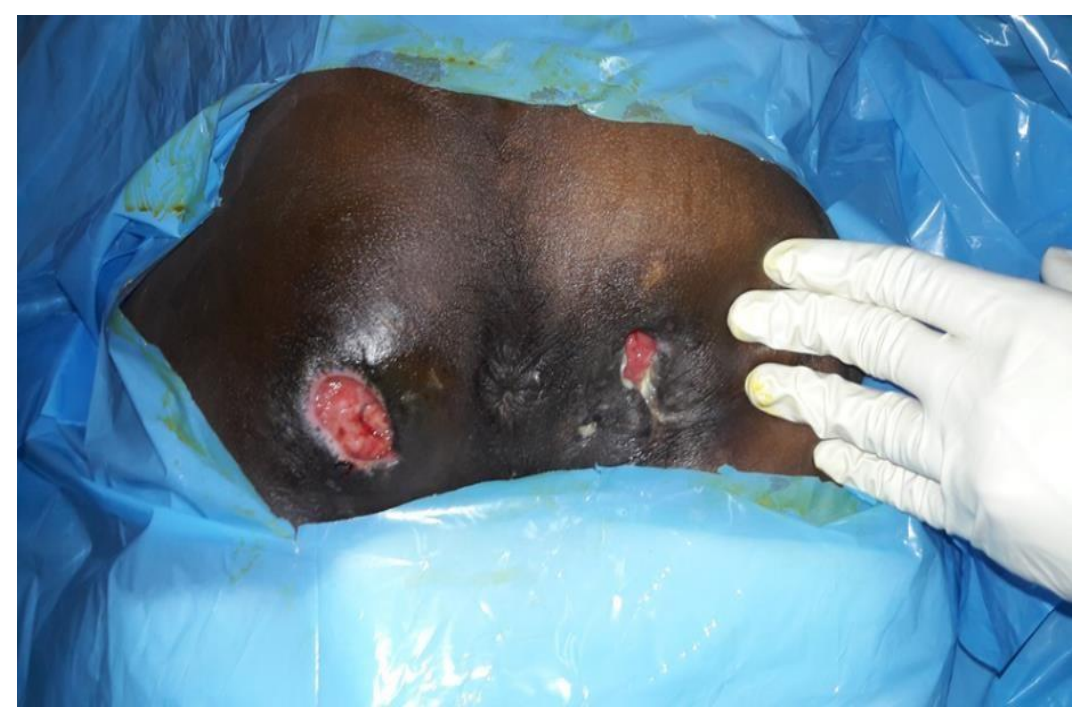

Figure 3. Wound bed with healthy granulation tissue.

\section{Results}

The application of topical insulin therapy helped in hastening theprocess of wound healing. It promoted healthy granulation tissue formation ( Figure 3.) and helped in planning for definitive reconstruction in the form of local flap later.

\section{Discussion}

Pressure sore or ulcer occurs at the area of prolong contact. Its site depends on position of the patient. The most common sites are-sacral region, heel, and occiput in the supine position, whereas the ischial region is the most common site in sitting position. Proper nursing care is required for its prevention. Once the pressure ulcer is developed, it is often hard to treat it. Often multi-disciplinary team approach is required. Various dressing methods and wound bed preparation methods have been advocated for pressure ulcer management, the topical insulin therapy is one such method.

Role of topical insulin in wound healing has been in literature since 1970s (1). Studies done in animal models and humans have found that topical Insulin therapy exerts its effects through the IGF 1 receptor. Insulin is known to stimulate keratinocytes and also the rate of endothelial proliferation leading to a faster neovascularization and also formation of granulation tissue (2). Topical insulin application rapidly induces upregulation of the insulin signalling related proteins on wound areas following injury.. IRS-1 binds the PI3-kinase, one of the $\mathrm{SH} 2$ proteins, through the multiple tyrosine phosphorylated sites $[3,4]$.

Insulin triggers the keratinocyte migration depending on the dose and time in the chronic wounds. Insulin demonstrates its effect through an insulin receptor dependent but EGF/EGF-R non-dependent way. The fact that it increases the keratinocyte migration on the PI3K-Akt-Rac1 pathway and cause stimulation of the keratinocytes by enabling the production of $\alpha 3$ and LN332 molecules has been proven by the in vitro studies $(6,7,8,9)$. Insulin is a hormone that also affects collagen production. Insulin selectively and strongly stimulates the collagen production in dermal fibroblasts $(10,11)$. The cost of insulin ranges from 130-500 INR per vial.

\section{Conclusion}

In this study, we found that insulin therapy has a role in the healing of the pressure ulcer and can be used as an adjuvant therapy for pressure ulcers. But since it is a single case study and a single institute study with no statistical analysis, definite conclusion cannot be made. Large 
randomized control trials are required to confirm the efficacy of topical insulin therapy in wound healing.

\section{References}

1. Belfield WO, Golinsky S, Compton MD. The use of insulin in open-wound healing. Vet Med Small Anim Clin. 1970;65(5):455-460.

2. Scimeca CL, Bharara M, Fisher TK, Kimbriel H, Mills JL, Armstrong DG. Novel use of insulin in continuous-instillation negative pressure wound therapy as "wound chemotherapy." J Diabetes Sci Technol 2010;4:820-4.

3. Hrynyk M, Neufeld RJ. Insulin and wound healing. Burns. 2014;40:1433-1446.

4. Takahashi Y, Tobe K, Kadowaki H, Katsumata D, Fukushima Y, Yazaki Y, Akanuma Y, Kadowaki T. Roles of insulin receptor substrate-1 and Shc on insulin-like growth factor I receptor signaling in early passages of cultured human fibroblasts. Endocrinology. 1997;138:741-750.

5. Garza-Garcia A, Patel DS, Gems D, Driscoll PC. RILM: a webbased resource to aid comparative and functional analysis of the insulin and IGF-1 receptor family. Hum Mutat. 2007;28:660668

6. Schilling JA. Wound healing. Surg Clin North Am 1976;56:859-74.

7. Coulombe PA. Wound epithelialization; accelerating the pace of discovery. J Invest Dermatol 2003;121:219-30.

8. Madibally SV, Solomon V, Mitchell RN, et al. Influence of insulin therapy on burn wound healing in rats. J Surg Res 2003;109:92-100.

9. Benoliel AM, Kahn-Perles B, Imbert J, Verrando P. Insulin stimulates haptotactic migration of human epidermal keratinocytes through activation of NF-kappa B transcription factor. J Cell Sci 1997;110:2089-97.

10. Chaiken RL, Moses AC, Usher P, Flier JS. Insulin stimulation of aminoisobutyric acid transport in human skin fibroblasts is mediated through both insulin and type I insulin-like growth factor receptors. J Clin Endocrinol Metab 1986; 63: 1181-5.

11. Flier JS, Usher P, Moses AC. Monoclonal antibody to the type I insulin-like growth factor (IGF-I) receptor blocks IGFI receptor-mediated DNA synthesis. Clarification of the mitogenic mechanisms of IGF-I and insulin in human skin fibroblasts. Proc Natl Acad Sci USA 1986; 83: 664-8. 